\title{
ANTIGENICITY, TOXICITY AND CROSS-REACTIONS OF MALE BAT (MYOTIS LUCIFUGUS) REPRODUCTIVE ORGANS
}

\author{
A. G. HUNTER, L. D. S. BARKER,* W. L. JOHNSON, \\ M. L. FAHNING AND R. H. SGHULTZ \\ Department of Animal Science, University of Minnesota, \\ St. Paul, Minnesota 55101, U.S.A. \\ (Received 18th October 1969, revised 12th May 1970)
}

\begin{abstract}
Summary. The antigenicity of male bat reproductive organs was studied using agar-gel diffusion. Four precipitin lines formed with testis and anti-testis, six lines with epididymis and anti-epididymis, and six lines with ampulla and anti-ampulla sera. Tissue extracts of liver, spleen, heart and uterus cross-reacted with the three antisera to produce three lines. Ampulla, epididymis and testis possessed at least one, three and one organ-specific antigens, respectively.

Nine proteins were detected in the seminal vesicles by agar-gel electrophoresis. One of these possessed potent toxic properties when injected into rabbits and mice. The toxic protein was isolated by zonal electrophoresis and by chromatography on Sephadex G-200. It migrated electrophoretically as a pre-albumin, had a molecular weight of approximately 44,600 and an $\mathrm{LD}_{50}$ value of $162 \mu \mathrm{g} / \mathrm{kg}$. The relationship between this protein and the unique phenomenon of bat sperm survival is unknown.
\end{abstract}

\section{INTRODUCTION}

Spermatogenic activity in the bat, Myotis lucifugus, occurs during the summer (Miller, 1945). Spermatogenesis is completed in September and precedes ovulation by about 7 months. During the winter months, the seminiferous tubules remain in an inactive state. During September, the male accessory glands attain their maximum size. Although the glandular epithelium then becomes inactive, the lumina of the accessory glands remains filled with secretion until spring. There is also an abundance of spermatozoa in the epididymides during hibernation, although spermatogenesis ceased in September.

Myotis lucifugus copulate in autumn. Spermatozoa have been found in the female reproductive tract throughout the hibernation period and into the spring (Miller, 1945). Spermatozoa from autumn inseminations are stored either

\footnotetext{
* Present address : Department of Biology, Southwest Minnesota State College, Marshall, Minnesota 56258 .
} 
in the uterus or in the vagina and remain viable throughout hibernation (Matthews, 1937; Wimsatt, 1944; Asdell, 1964). The ovaries of the hibernating bats contain viable follicles which rupture in the spring and only then does fertilization occur (Wimsatt, 1960). The physiological basis for the prolonged sperm survival (about 5 to 7 months) in the female is still unknown. Survival may involve special physiological adaptations in the spermatozoa, the uterus, or both. Wimsatt, Krutsch \& Napolitano (1966) reported only minor ultrastructural differences between epididymal and uterine spermatozoa.

The object of this paper was to characterize proteins present in the reproductive organs and glands of the male Myotis lucifugus. From such a characterization, it was hoped to gain some knowledge as to how prolonged sperm survival could occur.

\section{MATERIALS AND METHODS}

\section{Bat organs and tissues}

Approximately 150 little brown, male bats (Myotis lucifugus) from a wild population in the vicinity of St. Paul, Minnesota, were captured in the late summer and early autumn. The bats were bled and killed by decapitation within 1 or 2 days of capture. Testes, epididymides, ampullae, prostate, seminal vesicles, heart, liver, lung and kidney were removed, trimmed and stored in liquid nitrogen.

The testes of the bats collected for this study were still undergoing spermatogenesis and the accessory glands were in a plump secretory state.

The organs were thawed, suspended $(4 \% \mathrm{w} / \mathrm{v})$ in $0.005 \mathrm{M}$-phosphate buffered saline, $\mathrm{pH} 7 \cdot 4$, with a glass homogenizer and stored at $-20^{\circ} \mathrm{C}$.

\section{Immune sera and immunological tests}

The bat antigens $(4 \% \mathrm{w} / \mathrm{v})$ were testis, epididymis and ampulla. Three rabbits were immunized per antigen. Normal serum was obtained from all rabbits before immunization. The immunization scheme followed the protocol of Swanson \& Hunter (1969).

Ouchterlony precipitation in gel techniques were described previously (Hunter \& Hafs, 1964). However, in this study, plates were developed for 4 days at room temperature in a moist chamber.

\section{Toxin isolation}

Agar-gel electrophoresis in barbital buffer ( $\mathrm{pH} \mathrm{8.4, \mu}=0.05$ ) was performed on $4 \% \mathrm{w} / \mathrm{v}$ suspensions of bat seminal vesicles (BSV) according to the technique of Weime (1959). Electrophoresis was run for $20 \mathrm{~min}$ at $150 \mathrm{~V}$ and $40 \mathrm{~mA}$ per slide $(76 \times 26 \times 1 \mathrm{~mm})$. Following electrophoresis, two slides of each sample were divided in half. One half was stained with amido black for protein and quantified by densitometry. The other was divided into 2-mm sections. Each section was suspended in $1 \mathrm{ml}$ of $0.85 \%$ saline, left at $4^{\circ} \mathrm{C}$ overnight and then centrifuged at 12,000 $\mathrm{g}$ for $15 \mathrm{~min}$. Supernatant fluid ( $1 \mathrm{ml}$ ) was injected intraperitoneally into Swiss White mice $(0.5 \mathrm{ml} /$ mouse) weighing 15 to $25 \mathrm{~g}$. At least 
four mice were injected with fluid from duplicate sections. Deaths occurring between 6 and $24 \mathrm{hr}$ were recorded.

Procedures for chromatography on Sephadex G-200 and molecular weight determinations were described by Hunter \& Nornes (1969). BSV suspension $(0.5 \mathrm{ml}, 6 \mathrm{mg}$ protein) was eluted from the column $(1.1 \mathrm{~cm} \times 52 \mathrm{~cm})$ at the rate of $2.6 \mathrm{ml} / \mathrm{cm}^{2} / \mathrm{hr}$ at room temperature. Fractions $(2 \mathrm{ml})$ were collected volumetrically and assayed for protein and toxic activity.

Swiss White mice weighing 15 to $25 \mathrm{~g}$ were used to detect and assay toxicity. A minimal lethal dose was defined as the smallest amount of toxin required to kill a 22-g mouse within $24 \mathrm{hr}$ after intraperitoneal injection. For assay, aliquots $(0.5 \mathrm{ml})$ were injected intraperitoneally into mice. Two mice/dose were used routinely to detect toxicity and three mice/dose for the $\mathrm{LD}_{50}$ determination. The method of Reed \& Muench (1938) was used to determine the $\mathrm{LD}_{50}$ value.
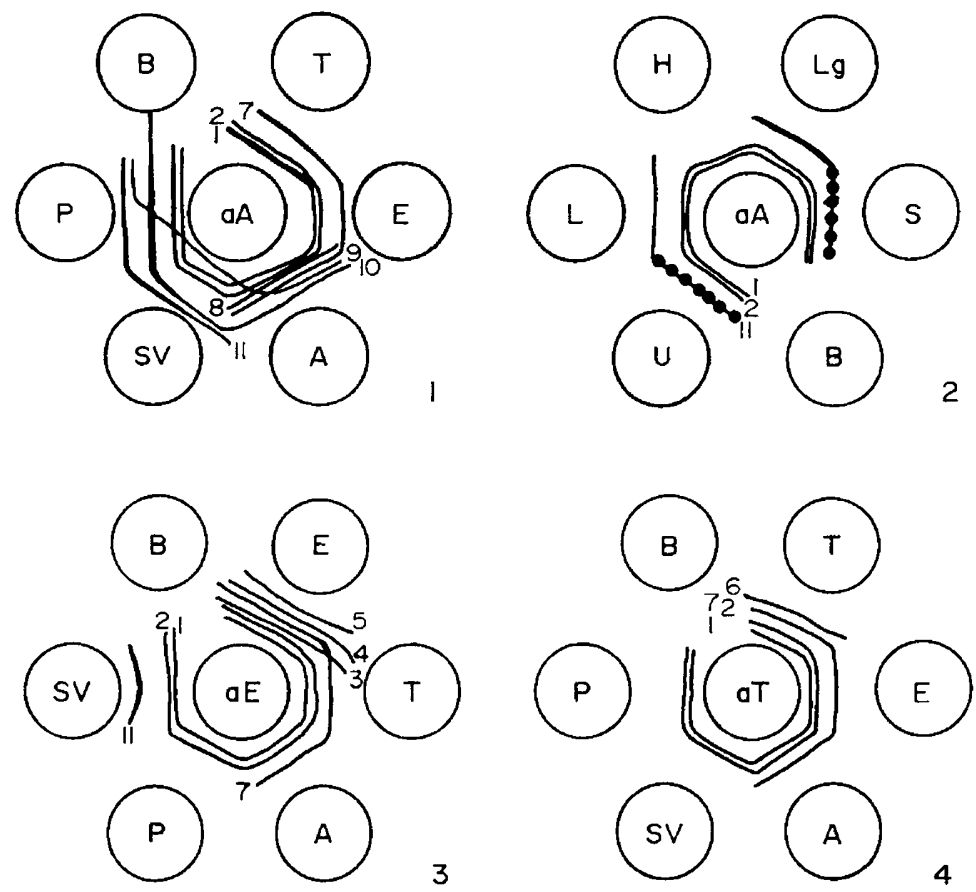

Text-FIG. 1. Precipitins induced in rabbit serum against bat reproductive tissues, body tissues and blood serum. Abbreviations: $\mathrm{aA}=$ rabbit anti-bat ampullae; aE = rabbit anti-bat epididymides; $\mathrm{aT}=$ rabbit anti-bat testes; $\mathrm{A}=$ ampulla; $\mathrm{B}=$ blood sera; $\mathrm{E}=$ epididymis; $\mathrm{H}=$ heart $; \mathrm{L}=$ liver; $\mathrm{Lg}=$ lung; $\mathrm{P}=$ prostate; $\mathrm{S}=$ spleen; $\mathrm{SV}=$ seminal vesicle; $\mathbf{T}=$ testis; $\mathrm{U}=$ uterus.

\section{RESULTS AND DISCUSSION}

\section{Agar-gel diffusion}

The reaction of heart, liver, lung, spleen and uterus with antisera to testes, epididymides or ampullae resulted in the formation of two to three lines (Textfig. 1). Blood sera failed to produce a line with these antisera (Text-fig. 1). 
Therefore, cross-reactivity between tissues was due to common tissue proteins rather than to common blood serum proteins.

The reaction of testes, epididymides, ampullae, prostate and seminal vesicles with the three antisera are presented in Text-fig. 1. Testicular material possessed four antigens. Two of these were antigens common to heart, liver, lung and spleen; one was specific to testis, and one was present in suspensions of epididymides and ampullae.

Epididymal suspensions possessed six antigens (Text-fig. 1). Two were antigens common to heart, liver, lung and spleen; three were detected only in the epididymis, and one antigen was detected in both testis and ampulla. Apparently, at least three antigens were specific for epididymis.

Ampullar suspensions possessed six antigens (Text-fig. I). Two were the common cross-reacting tissue antigens; one was shared with testis and epididymis; one was specific to the ampulla, and two were also present in suspensions

TABLE 1

ANTIGENIC SPEGTRUM* IN VARIOUS BAT REPRODUCTIVE TISSUES

\begin{tabular}{|c|c|c|c|c|c|c|}
\hline \multirow{2}{*}{ Antigen $\dagger$} & \multicolumn{6}{|c|}{ Present in: } \\
\hline & Testis & Epididymis & Ampulla & $\begin{array}{c}\text { Seminal } \\
\text { vesicle }\end{array}$ & Prostate & Liver \\
\hline 11 & • & . & - & + & + & + \\
\hline 10 & . & . & + & + & + & . \\
\hline 9 & . & . & + & + & + & . \\
\hline 8 & . & . & + & . & . & . \\
\hline 7 & $\dot{t}$ & + & + & . & . & . \\
\hline 6 & + & . & . & . & . & . \\
\hline 5 & . & + & . & . & . & . \\
\hline 4 & . & + & . & . & . & . \\
\hline 3 & . & + & . & . & . & . \\
\hline 2 & + & + & + & + & + & + \\
\hline $\overrightarrow{1}$ & + & + & + & + & + & + \\
\hline
\end{tabular}

* As determined by the Ouchterlony technique with rabbit antisera to testes, epididymides and ampullae.

$\uparrow$ Refers to numbers seen in Text-fig. 1 .

of prostate and seminal vesicle. The last two antigens probably originated within the accessory sex glands and leaked into the ampullar region during ejaculation or as a result of muscular contractions.

Table 1 presents a summary of the antigenic spectrum of bat seminal products. In summary, the antigenic spectrum and cross-reactivity of male bat reproductive organs did not differ drastically from that reported for species in which the spermatozoa have a limited life-span (bulls-Matousek, 1964; boars-Schellpfeffer, 1969; humans-Quinlivan, 1969; rabbits-Hunter, 1969).

\section{Seminal vesicle toxicity}

Anti-bat seminal vesicle-immune sera was not obtained as all twelve rabbits died within $24 \mathrm{hr}$ after injection of BSV suspension. At necropsy, the only observed gross pathological changes were extremely swollen small and large intestines. Despite tremendous fluid accumulation in the intestines, no external 
signs of diarrhoea or defaecation were present. This finding contrasted with anything this author has observed while working with seminal products of bulls, boars, humans, rabbits and rams. Weil, Roberts \& Dube (1964) reported that a constituent of guinea-pig seminal vesicles (cobayin) was highly toxic to rabbits on parenteral application. Injections of cobayin produced a flushing of the ears, followed by laboured breathing, diarrhoea, weakness and signs of severe intoxication.

Agar-gel electrophoresis of BSV extract revealed nine proteins; seven of which were on the anode side of the 'origin' (Text-fig. 2). Approximately $51 \%$ of the protein migrated with an electrophoretic mobility greater than bat serum

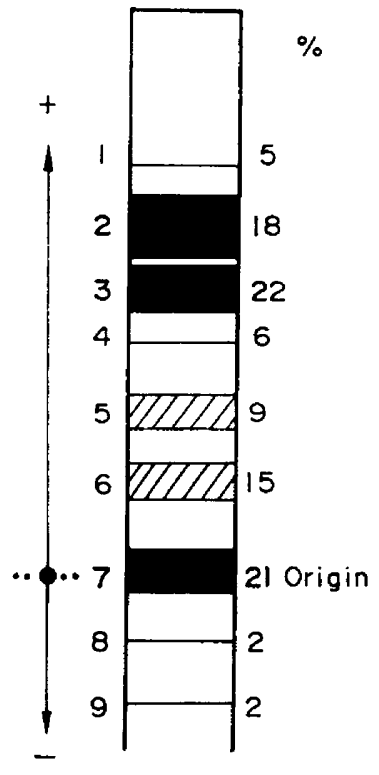

A

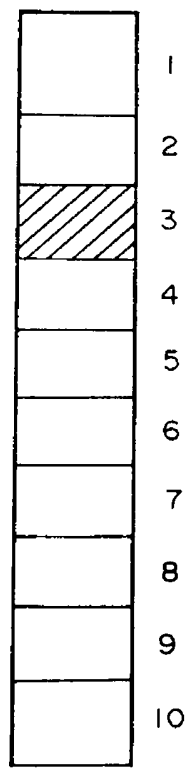

B

TEXT-FIG. 2. Bat seminal vesicle agar-gel electrophoresis pattern. The drawing indicates the position of the major protein bands (A) and the location of toxic activity (B) after electrophoresis of $0.1 \mathrm{ml}$ of BSV preparation. Electrophoresis was conducted with veronal buffer, $\mathrm{pH} 8.6$, at $40 \mathrm{~mA} /$ slide at room temperature. Bat serum albumin under the same electrophoretic conditions would be found in zone 5 of $\mathbf{B}$.

albumin. This electrophoretic pattern contrasted markedly with that reported for boar, bull, ram and rabbit seminal plasma (Bennett, 1965).

After elution of each protein zone from the agar, toxic activity was associated only with protein band 2 (Text-fig. 2). This protein constituted approximately $18 \%$ of the total protein of the BSV material. All six mice which were injected with this protein died within 6 to $24 \mathrm{hr}$ and showed the same post-mortem picture as that seen in rabbits. Injections of the other protein fractions of BSV failed to kill any mice.

Chromatography of BSV suspension on Sephadex G-200 produced four peaks (Text-fig. 3). The retention values of these peaks corresponded to molecular weight components of 113,000,44,600, 11,200 and 160. Toxic 
activity was found only within fraction $B$, the peak associated with 44,600 molecular weight components.

The toxicity of BSV suspension, calculated as an $\mathrm{LD}_{50}$, was $900 \mu \mathrm{g} / \mathrm{kg}$ or $0.02 \mathrm{mg} /$ mouse. Since only $18 \%$ of the total protein was associated with toxic activity (Text-fig. 3), these figures would be $162 \mu \mathrm{g} / \mathrm{kg}$ or $0.0036 \mathrm{mg} / \mathrm{mouse}$ on a partially purified basis. The toxicity calculated as a minimal lethal dose for whole suspension was $1020 \mu \mathrm{g} / \mathrm{kg}$ or $0.22 \mathrm{mg} /$ mouse and on the partially purified basis was $184 \mu \mathrm{g} / \mathrm{kg}$ or $0.004 \mathrm{mg} /$ mouse. These values rank BSV equivalent to rattlesnake (Crotalus) venom as a toxin (Russell, 1967).

The $\mathrm{LD}_{50}$ in mice for BSV on a fresh weight basis was $0.2 \mathrm{mg}$ of tissue. This

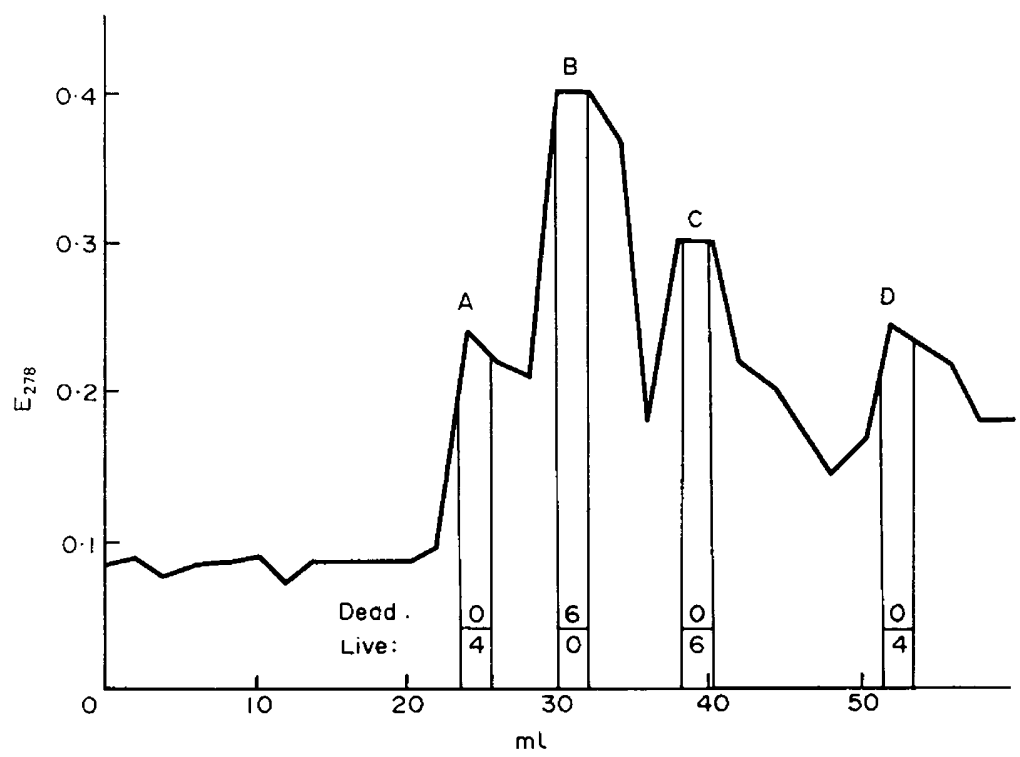

TEXT-FIG. 3. Protein elution pattern for bat seminal vesicle material chromatographed on Sephadex G-200 with subsequent analysis of peak fraction for toxicity in mice. Average molecular weights of peaks: $A=113,000, B=44,600, C=11,200$ and $D=160$.

was ten times more potent than a toxin found in the submaxillary gland of the short-tailed shrew, Blarina brevicauda, by Pearson (1956).

The protein pattern and physiological activity of BSV differs greatly from that found in other species and would seem to merit further investigation in seeking an explanation for the longevity of bat spermatozoa.

\section{ACKNOWLEDGMENTS}

This paper is Journal Article No. 7065 from the Minnesota Agricultural Experiment Station. This investigation was supported in part by USPHS grant HD-00816 and the Maud and Louis Hill Family Foundation.

\section{REFERENGES}

Asoelc, S. A. (1964) Patterns of mammalian reproduction, p. 96. Comstock, Ithaca, New York.

Bennett, J. P. (1965) Quantitative comparisons of the proteins of the seminal plasmas of bull, ram, rabbit and boar by agar gel electrophoresis. 7. Reprod. Fert. 9, 217. 
Hunter, A. G. (1969) Differentiation of rabbit sperm antigens from those of seminal plasma. J. Reprod. Fert. 20, 413.

Hunter, A. G. \& Hafs, H. D. (1964) Antigenicity and cross-reactions of bovine spermatozoa. $\mathcal{J}$. Reprod. Fert. 7, 357.

Hunter, A. G. \& Nornes, H. O. (1969) Characterization and isolation of a sperm-coating antigen from rabbit seminal plasma with capacity to block fertilization. F. Reprod. Fert. 20, 419.

Matousek, J. (1964) Antigenic characteristics of spermatozoa from bulls, rams and boars. F. Reprod. Fert. 8, 1.

Matthews, L. H. (1937) The female sexual cycle in the British horseshoe bats, Rhinolophus ferrumequinum insulanus Barrett-Hamilton and $R$. hipposideros minutus Montagu. Trans. zool. Soc. Lond. 23, 224.

Miller, R. E. (1945) The reproduction cycle in male bats of the species Myotis lucifugus and Myotis grisescens. 7. Morph. 64, 267.

Pearson, O. P. (1956) A toxic substance from the salivary glands of a mammal (Short-tailed shrew). In: Venoms, p. 55. Eds. E. E. Buckley and N. Porges. Publication No. 44, Am. Assoc. Adv. Sci., Washington.

Quinervan, W. L. G. (1969) The specific antigens of human seminal plasma. Fert. Steril. 20, 58.

ReEd, L. J. \& Muench, H. (1938) Simple method of estimating 50 percent end points. Am. F. Hyg. $27,493$.

Russell, F. E. (1967) Pharmacology of animal venoms. Clin. Pharmac. Ther. 8, 849.

SCHELLPFEFFER, D. A. (1969) The antigenic composition of porcine semen and its alteration by removal of accessory sex glands. M.S. thesis, University of Minnesota.

Swanson, L. V. \& Hunter, A. G. (1969) Egg yolk antigens and their effect on fertility in rabbits. Biol. Reprod. 1, 324.

Weil, A. J., Roberts, C. O. \& Dube, A. (1964) Cobayin: A poisonous principle in the guinea pig's seminal plasma. Proc. Soc. exp. Biol. Med. 117, 896.

Weime, R. J. (1959) Studies on agar gel electrophoresis. Techniques-applications. Arscia Uitagaven N.V., Brussels.

Wimsatt, W. A. (1944) Further studies on the survival of spermatozoa in the female reproductive tract of the bat. Anat. Rec. 88, 193.

Wimsatr, W. A. (1960) Some problems of reproduction in relation to hibernation in bats. Bull. Mus. comp. Zool. Harv. 124, 249.

Wimsatt, W. A., Krutzsch, P. H. \& Napolitano, L. (1966) Studies on sperm survival mechanisms in the female reproductive tract of hibernating bats. Am. F. Anat. 119, 25. 